\title{
Summaries of Toxicity Studies on Mepiquat-Chloride
}

\author{
Registration Department, Agricultural Chemicals Division, BASF Japan Ltd.
}

(Received May 20, 1992)

\section{DESCRIPTION OF THE TEST COMPOUND}

Mepiquat-chloride is a chemical developed by BASF Aktiengesellschaft in early 1970s. Through a number of trials in which its biological activity was tested, it has been confirmed that Mepiquat-chloride is an effective plant growth regulator. Mepiquat-chloride has been mainly used for yield increase of cotton in USA under the trade name of PIX. This article provides a toxicological feature of Mepiquatchloride obtained from numerous toxicological studies with the solid technical grade (hereafter as MEPIQUAT-C1 TECH), the liquid technical grade (hereafter as MEPIQUAT-C1 LIQTECH), and the $44 \%$ liquid concentration (hereafter as FRASTAR LC).

The chemical structure and physical properties of Mepiquat-chloride are given below:

Common name: Mepiquat-chloride

Chemical name: 1,1-Dimethylpiperidinium chloride (CAS Reg. No. 24307-26-4)

Structural formula:

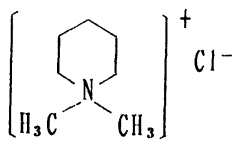

Molecular formula: $\mathrm{C}_{7} \mathrm{H}_{16} \mathrm{ClN}$

Molecular weight: 149.7

Appearance: White crystals

Melting point: $285^{\circ} \mathrm{C}$

Vapor pressure: $<1 \times 10^{-7} \mathrm{mbar}\left(50^{\circ} \mathrm{C}\right)$

Solubility $\left(\mathrm{g} / 100 \mathrm{~g}\right.$ solvent at $\left.20^{\circ} \mathrm{C}\right)$ : Water $>50$, methyl alcohol 25.0, ethyl alcohol 16.2, chloroform 1.1, acetone $<0.1$, benzene $<0.1$, cyclohexanone $<0.1$, diethyl ether $<0.1$, olive oil $<0.1$.

Partition coefficient ( $n$-octanol/water): Log $P_{\text {ow }}-2.83$ (mean value of 3 measurements at different concentrations).

Stability: No decomposition at $50^{\circ} \mathrm{C}$ for 2 years in an unopened original package. No decomposition in the respective buffer solutions of $\mathrm{pH} 1-2$ and $12-13$ at $95^{\circ} \mathrm{C}$ for 7 days. Half life longer than 24 hours in exposure at $238-579 \mathrm{~nm}\left(15 \mathrm{~cm}\right.$ distance, $\left.20^{\circ} \mathrm{C}\right)$.

\section{ACUTE TOXICITY}

Table 1 shows results of acute toxicity studies with MEPIQUAT-C1 TECH, MEPIQUAT-C1 LIQ-TECH and FRESTAR LC at different routes of administration.

In these tests, the administration of the respective test substances via different routes

Table 1

\begin{tabular}{|c|c|c|c|c|}
\hline \multirow{2}{*}{$\begin{array}{c}\text { Test } \\
\text { substance }\end{array}$} & \multirow{2}{*}{$\begin{array}{l}\text { Animal } \\
\text { species, } \\
\text { strain }\end{array}$} & \multirow{2}{*}{$\begin{array}{l}\text { Administra- } \\
\text { tion } \\
\text { route }\end{array}$} & $\mathrm{LD}_{50}(\mathrm{mg} / \mathrm{kg})$ & \multirow{2}{*}{ Testing facility, reporting year } \\
\hline & & & Female & \\
\hline $\begin{array}{l}\text { MEPIQUAT-C1 } \\
\text { TECH }\end{array}$ & Rat, SD & Inhalation & $>3.2 \mathrm{mg} / \mathrm{l}$ & Department of Toxicology, BASF, 1984 \\
\hline \multirow{3}{*}{$\begin{array}{l}\text { MEPIQUAT-C1 } \\
\text { LIQ-TECH }\end{array}$} & Rat, Wistar & Oral & ca. 464 & Department of Toxicology, BASF, 1984 \\
\hline & Mouse, NMRI & Oral & \multirow{2}{*}{$\begin{array}{r}780 \\
>2000\end{array}$} & Department of Toxicology, BASF, 1984 \\
\hline & Rat, Wistar & Dermal & & Department of Toxicology, BASF, 1984 \\
\hline \multirow[t]{3}{*}{ FRASTAR LC } & Rat, SD & Oral & $3200 \quad 3180$ & Department of Toxicology, BASF, 1984 \\
\hline & Rat, SD & Dermal & \multirow{2}{*}{$\begin{array}{r}>5000 \\
>3.9 \mathrm{mg} / \mathrm{l}\end{array}$} & Department of Toxicology, BASF, 1984 \\
\hline & Rat, SD & Inhalation & & Department of Toxicology, BASF, 1984 \\
\hline
\end{tabular}


caused non-specific signs of toxicity.

\section{LOCAL IRRITATION AND SENSITIZATION}

Instillation of MEPIQUAT-C1 TECH (about $0.1 \mathrm{~g} /$ eye) into the conjunctival sac of the eye of rabbits induced hardly any irritant effects on the conjunctiva.

(Laboratorium für Pharmakologie und Toxikologie, 1977)

FRASTAR LC (about $0.1 \mathrm{ml} /$ eye) induced a very slight reddening of the lid conjunctiva of rabbits which was only observable in one animal after 7 days.

(Department of Toxicology, BASF, 1977)

The local irritation was tested on the intact and abraded dorsal skin of rabbits by applying the test substance under an occlusive dressing for 24 hours. The applied quantity of $0.5 \mathrm{~g} /$ animal caused no irritant reactions in either the intact or the abraded rabbit skin.

(Laboratorium für Pharmakologie und Toxikologie, 1976)

FRASTAR LC (about $0.5 \mathrm{~g} /$ patch) caused a very slight reddening on intact skin 24 hours after application, which was quickly reversible. On the abraded skin, varying degrees of reddening and oedema were observed, but were reversible within 7 days.

(Department of Toxicology, BASF, 1977)

No sensitizing potential was indicated when MEPIQUAT-C1 TECH was tested for its skin sensitizing effect on the skin of guinea pigs.

(Department of Toxicology, BASF, 1979)

\section{SUBACUTE TOXICITY STUDIES}

A four-week range-finding study was performed with SD rats, administering 0 and $10,000 \mathrm{ppm}$ MEPIQUAT-Cl TECH to 35 animals/sex and dose and 250, 1000 and 2500 ppm to 25 animals/sex and dose in the food.

The major effect attributable to the test substance was an inhibition of body weight gain at dose levels of $2500 \mathrm{ppm}$ and higher. The NOEL is, therefore, established to be 1000 ppm ( $=109.3 \mathrm{mg} / \mathrm{kg}$ b.w. in both sexes).

(Laboratorium für Pharmakologie und Toxikologie, 1976)

\section{SUBCHRONIC TOXICITY STUDIES}

In a three-month study, $25 \mathrm{SD}$ rats/sex and dose were administered MEPIQUAT-Cl TECH at dose levels of $0,100,300,1000$ and 3000 ppm in the food.

Major effects attributable to the test substance were an inhibition of body weight gain at $3000 \mathrm{ppm}$ and reduced absolute organ weights; heart, lungs, spleen, kidney and liver. The latter finding was noticed at $3000 \mathrm{ppm}$ in male animals and should be seen in connection with the decreased body weight. The NOEL is $1000 \mathrm{ppm}$ ( $=91.8 \mathrm{mg} / \mathrm{kg} \mathrm{b.w}$. in males and $91.2 \mathrm{mg} / \mathrm{kg}$ b.w. in females).

(Laboratorium für Pharmakologie und Toxikologie, 1977)

Beagle dogs, 4 dogs/sex and dose, were administered MEPIQUAT-Cl TECH at dose levels of $0,100,300,1000$ and $3000 \mathrm{ppm}$ in the food for a period of three months.

The administration of the highest dose (3000 ppm) caused an inhibition of body weight gain and changes in some haematological parameters. The three lower concentrations were tolerated without reactions. Based on the findings of this study, the NOEL is $1000 \mathrm{ppm}(=32.4 \mathrm{mg} / \mathrm{kg}$ b.w. in both sexes).

(Laboratorium für Pharmakologie und Toxikologie, 1977)

\section{CHRONIC TOXICITY AND ONCOGENICITY}

A combined chronic and carcinogenicity study was performed with SD rats for a period of 104 weeks. Animals of 105/sex were used as control. Animals of 50/sex and dose were administered 100, 300 and 1000 ppm MEPIQUAT-Cl TECH in the food, whereas 3000 $\mathrm{ppm}$ were administered to 55 animals/sex and $9000 \mathrm{ppm}$ to 35 animals/sex.

The tumors did not, in respect to their nature, extent and time of occurrence, show an influence of the test substance. The administration of the test substance did not influence clinical parameters, hematology, urinalysis or clinical biochemistry. At $9000 \mathrm{ppm}$, a statistically significant decreased body weight was observed. The slight (statistically not significant) reduction in body weight which occurred during a part of the study at 3000 ppm was not considered to be of toxicological relevance. No pathological changes were observed. Based on the findings of this study, the NOEL is $3000 \mathrm{ppm}(=186.0 \mathrm{mg} / \mathrm{kg}$ b.w. 
in males and $211.9 \mathrm{mg} / \mathrm{kg}$ b.w. in females). There were no signs of a carcinogenic potential.

(Laboratorium für Pharmakologie und Toxikologie, 1979)

Another combined chronic and carcinogenicity study was performed with NMRI mice for a period of 104 weeks. Animals of 100/sex were used as control, whereas 50 animals/sex and dose were administered 100,300, 1000 and 3000 ppm MEPIQUAT-Cl TECH in the food.

In this study, the findings were almost identical to those found in the aforesaid long term toxicity study in rats. The NOEL is $1000 \mathrm{ppm}(=169.4 \mathrm{mg} / \mathrm{kg}$ b.w. in males and $226.1 \mathrm{mg} / \mathrm{kg}$ b.w. in females). No signs of a carcinogenic potential were confirmed in this study either.

(Lakoratorium für Pharmakologie und Toxikologie, 1979)

In a twelve-month feeding study in Beagle dogs, 6 animals/sex and dose were administered doses of $0,200,600$ and 1600 ppm MEPIQUAT-Cl TECH via the diet.

At $1800 \mathrm{ppm}$, a very slightly increased iron pigment storage in the spleen and liver of male animals was observed. No substance-related findings were noted in the females. Therefore the NOEL is $600 \mathrm{ppm}$ (=19.9 $\mathrm{mg} / \mathrm{kg}$ b.w.) for males and $>1800 \mathrm{ppm}(=>58.4 \mathrm{mg} / \mathrm{kg}$ b.w. $)$ for females.

(Department of Toxicology, BASF, 1989)

\section{TERATOGENICITY AND REPRODUCTION STUDY}

The effect of MEPIQUAT-Cl TECH on reproduction was tested with SD rats in a threegeneration study using two litters in each generation. Forty animals/sex and dose were administered the test substance at dose levels of $0,319.1,1063.8$ and $3191.5 \mathrm{ppm}$ in the food. Parental animals $\left(\mathrm{F}_{0}\right)$ were mated to produce a first litter $\left(\mathrm{F}_{1 \mathrm{a}}\right)$, and they were subsequently remated to produce a second litter $\left(F_{1 b}\right)$, which were retained only until weaning. From the $F_{1 b}, 40$ animals/sex and dose were selected for the subsequent parental generation. After weaning, they were fed the same food as their parents until mating for producing the respective litters; $F_{2 a}$ and $F_{2 b}$. The other 20 dams of $F_{1 a}$ were laparotomised at the 20th day of pregnancy and examined for possible teratogenic changes. The said procedures were repeated until $F_{3 b}$ litters. Twenty animals of the $\mathrm{F}_{3}$-generation were observed for approx. 9 weeks, and 10 of them were examined microscopically.

The fertility and breeding capacity were not influenced in any generation, and mating behavior, duration of pregnancy, litter size, birth weight of pups and breeding rate were within the normal range. The indices of fertility, gestation, viability and lactation corresponded in experimental and control animals. Behavior and external development of the young animals showed no difference in comparison with the control. No toxic effects were seen in the fetuses. Malformations did not occur. All the animals tolerated the administration of the test substance, showing no changes in clinical parameters. The comparison of organ weights and the histological investigation in 10 animals/group/sex of the $\mathrm{F}_{3}$-generation 9 weeks after birth disclosed no changes attributable to the administration of the test substance. Based on the findings of this study, the NOEL is $3191.5 \mathrm{ppm} \quad(=256.6-378.7 \mathrm{mg} / \mathrm{kg} \quad$ b.w. in males and $374.6-424.5 \mathrm{mg} / \mathrm{kg}$ b.w. in females).

(Laboratorium für Pharmakologie und Toxikologie, 1979)

To assess the pre-, peri- and postnatal toxicity of MEPIQUAT-Cl TECH, groups of 35 pregnant SD rats were orally administered the test substance ad libitum in the ground food at dose levels of $0,100,300,1000$ and $3,000 \mathrm{ppm}$. Twenty-five animals of each group were administered the test substance from day 0 to the 20th day post coitum. The remaining 10 animals received the test substance from day 0 post coitum to the 21 st day post partum. Some of the rats were sacrificed on the 20th day post coitum and the fetuses were delivered by Cesarean section. The other animals were allowed to give birth spontaneously and rear the pups up to the 21st day post partum.

The test substance was tolerated by the animals without any changes in clinical parameters. Delivery, date of delivery and litter size remained unaffected. There was no influence noted on the body weight, body weight gain, development, viability and behavior of the pups. No pathological changes to the pups were recognized macroscopically. 
Under the test conditions chosen, NOEL is 100 ppm for dams and their offspring. No teratogenic effects were detected at the dose levels tested.

(Department of Toxicology, BASF, 1977)

In a further study, MEPIQUAT-Cl TECH was tested for its prenatal toxicity in Himalayan rabbits. Groups of 22 animals were used as control, received aqua bidest or $150 \mathrm{mg} / \mathrm{kg}$ b.w. of the test substance. Groups of 21 animals were administered 50 and $100 \mathrm{mg} / \mathrm{kg}$ b.w. respectively. All the animals were sacrificed on day 28 post insemination and the fetuses delivered by Cesarean section.

The administration of $50 \mathrm{mg} / \mathrm{kg}$ b.w. was tolerated without any clinically detectable symptoms of poisoning. In addition, a transient reduction of food consumption was observed. However, as there were no clear effects on body weight, and, in a follow-up study, no effects were seen at higher dose levels, this was considered incidental. One animal had an abortion. There were no macroscopically observable pathological changes at the autopsy of the animals. No substancerelated influence were observed on the number of implants or on the number of viable and dead fetuses. The weight of the fetuses, their length and the weight of the placentae were within the spontaneous scatter range as were the type and number of variations and/or retardations. The doses of 100 and $150 \mathrm{mg} / \mathrm{kg}$ b.w. caused some clinically observable symptoms such as trembling, apathy and spasms. The reduced food consumption and body weight gain are to be associated with the test substance administration. At $150 \mathrm{mg} / \mathrm{kg}$, seven animals died. Some animals had an abortion. The autopsy did not give indication of any compound-related macroscopically detectable pathological changes of the internal organs. There was a slight reduction in the weight of the fetuses and in the weight of the placentae. One fetus exhibited anomaly. On the basis of these findings, the NOEL for maternal toxicity is $50 \mathrm{mg} / \mathrm{kg} \mathrm{b.w}$. The toxic dose for fetuses is expected to be from/above $150 \mathrm{mg} / \mathrm{kg}$ b.w. No teratogenic properties of the test substance were observed.

(Department of Toxicology, BASF, 1979)

A further prenatal toxicity study in rabbits was carried out with groups of 15 female Himalayan rabbits. MEPIQUAT-Cl TECH was administered orally at dose levels of 0,75 and $100 \mathrm{mg} / \mathrm{kg}$ b.w. from day 6 to day 18 post insemination. The fetuses were delivered by Cesarean section on day 29 post insemination.

Both doses, 75 and $100 \mathrm{mg} / \mathrm{kg}$ b.w., were tolerated without any symptoms. Food consumption and body weight gain were not affected by the test substance. No teratogenic effect was detected at the dose levels tested.

(Department of Toxicology, BASF, 1981)

\section{MUTAGENICITY STUDIES}

DNA repair was investigated using Bacillus subtilis, strains $\mathrm{H} 17\left(\mathrm{Rec}^{+}\right)$and $\mathrm{M} 45\left(\mathrm{Rec}^{-}\right)$. MEPIQUAT-Cl TECH doses, dissolved in distilled water, ranged from 2484 to $39,740 \mu \mathrm{g} /$ plate without metabolic activation (rat liver homogenate), and from 1242 to $19,870 \mu \mathrm{g} /$ plate with metabolic activation.

At all dose levels with and without metabolic activation, no indication for DNA damage was observed.

(Toxicological Institute, Nippon Soda, 1989)

Genetic damage resulting from gene mutation was investigated in the Ames test using Salmonella typhimurium, strains TA 98, TA 100, TA 1535 and TA 1537, and Escherichia coli, strain WP2 uvrA, with and without metabolic activation (rat liver homogenate). The doses of MEPIQUAT-Cl TECH, dissolved in distilled water, ranged from 156.3 to 5000 $\mu \mathrm{g} /$ plate.

No significant increases in the numbers of revertant colonies of bacteria were recorded for any of the bacteria strains tested. Therefore MEPIQUAT-Cl TECH is not mutagenic in the Ames test.

(Toxicological Institute, Nippon Soda, 1989)

Genetic damage through chromosomal aberration was investigated in vitro with chinese hamster ovary $(\mathrm{CHO})$ cells. MEPIQUAT-Cl TECH was tested at dose levels of 2.0, 3.0, 4.0 and $5.0 \mathrm{mg} / \mathrm{ml}$ with and without metabolic activation (rat liver enzymes, NADP and isocitric acid).

MEPIQUAT-Cl TECH was inactive in inducing chromosomal aberrations under both the metabolic activation and nonactivation 
conditions of this study.

(Hazleton Biotechnologies, 1987)

In the in vitro unscheduled DNA synthesis (UDS) assay, MEPIQUAT-Cl TECH was tested for its potential to induce increases in UDS. Primary rat hepatocytes were exposed to MEPIQUAT-Cl TECH in concentrations ranging from $0.026 \mu \mathrm{g} / \mathrm{ml}$ to $5000 \mu \mathrm{g} / \mathrm{ml}$. As treatments at 5000 and $4000 \mu \mathrm{g} / \mathrm{ml}$ were excessively toxic, treatments from 25.6 to 3000 $\mu \mathrm{g} / \mathrm{ml}$ were analyzed for UDS.

MEPIQUAT-Cl TECH did not induce significant changes in the nuclear labeling of primary rat hepatocytes at the concentrations tested. Therefore Mepiquat-chloride was not active in the UDS assay.

(Hazleton Laboratories America, 1987)

MEPIQUAT-Cl TECH was also tested for mutagenic properties (Dominant Lethal Genes) in male NMRI mice by oral administration of the test substance at dose levels of 100, 300, 1000 and $3000 \mathrm{ppm}$ in the food.

There were no indications for mutagenic properties. Fertility remained within normal limits, and no changes were observed in clinical parameters. MEPIQUAT-Cl TECH was, therefore, negative in this test.

(Laboratorium für Pharmakologie und Toxikologie, 1977)

\section{GENERAL PHARMACOLOGY}

\section{Effects on Central Nervous System}

Male ddy mice of 3/dose were administered MEPIQUAT-Cl TECH at dose levels of 125 , 250 and $500 \mathrm{mg} / \mathrm{kg}$ b.w. by oral gavage. Male New Zealand White rabbits of $3 /$ dose were administered the test substance intraveneously at dose levels of 5,15 and $45 \mathrm{mg} / \mathrm{kg}$ b.w.

The most obvious changes in behavior in mice were the decrease of motor activity, motor incoordination and loss of muscle tone, etc., whereas in rabbits a decrease of motor activity, motor incoordination, salivation, cyanosis and nictitating membrane closing were noticed.

\section{Effects on Autonomic Nervous System and Smooth Muscle}

Effect on isolated ileum was tested with ileum specimens prepared from 4 male Hartley guinea pigs and suspended in organ bath solu- tion which contained MEPIQUAT-Cl TECH at concentrations of $10^{-7}-3 \times 10^{-2} \mathrm{~g} / \mathrm{ml}$.

The contraction of isolated guinea pig ileum was induced by the test substance, and inhibited by atropine sulfate, hexamethonium chloride and diphenhydramine hydrochloride.

\section{Effects on Blood Pressure, Heart Rate and Respiration}

Male New Zealand White rabbits of 6/dose were used for the test. MEPIQUAT-Cl TECH was dissolved in $0.9 \%$ physiological saline solution and injected from the cannula inserted into the left femoral vein in doses of 0.04, 0.2 and $1 \mathrm{mg} / \mathrm{kg}$ b.w. Atropine sulfate and diphenhydramine hydrochloride were coinjected with MEPIQUAT-Cl TECH in the same way at doses of $1 \mathrm{mg} / \mathrm{kg}$ b.w. and $2 \mathrm{mg} / \mathrm{kg}$ b.w. respectively.

At $1 \mathrm{mg} / \mathrm{kg}$ b.w., the test substance depressed the blood pressure and heart rate for a short time, and the respiration became shallow. The blood pressure was also depressed at 0.2 $\mathrm{mg} / \mathrm{kg}$ b.w., however, $0.04 \mathrm{mg} / \mathrm{kg}$ b.w. had no effect on these parameters. The influence of $1 \mathrm{mg} / \mathrm{kg}$ of the test substance was inhibited by pre-administered atropine sulfate and slightly inhibited by pre-administered diphenhydramine hydrochloride.

\section{Effects on Blood}

\subsection{Effect on blood coagulation}

Male Wistar rats of 6 or $5 /$ dose were intraperitoneally injected the test substance at dose levels of 3,10 and $30 \mathrm{mg} / \mathrm{kg}$ b.w. dissolved in $0.9 \%$ physiological saline solution. Blood was taken from the abdominal aorta 1 hour after the injection.

The test substance had no effect on the ex vivo blood coagulation time.

\subsection{Effect on hemolysis}

One male New Zealand White rabbit/concentration was used for the test. Blood was taken from the ear artery of the rabbits and an erythrocyte solution was prepared. Then the test substance, dissolved in $0.9 \%$ physiological saline solution, was mixed with the erythrocyte solution to final concentrations of $0.2,0.6$ and $2.0 \mathrm{mg} / \mathrm{ml}$.

The test substance had no hemolysis effect. (Toxicological Institute, Nippon Soda, 1990) 


\section{SUMMARY}

In order to investigate toxicological properties of Mepiquat-chloride, a number of toxicological studjes were carried out with MEPIQUAT-Cl TECH, MEPIQUAT-Cl LIQTECH and/or FRASTAR LC. From these studies, it can be derived that the acute toxicity, subacute toxicity, and long-term toxicity are rather low. Weak irritant effects on eye and skin were noted, but no skin sensitizing effect was observed. Inhalation risk can be excluded under practical conditions. No adverse effect was observed on reproduction parameters, and no signs of teratogenic effects were noted. Mepiquat-chloride was neither mutagenic nor oncogenic in the studies performed.
A withholding value has been set for the registration at $2.0 \mathrm{ppm}$ on fruits, and FRASTAR LC, liquid concentration formulation containing $44.0 \%$ Mepiquat-chloride, was registered to JMAFF on April 1, 1991 as a plant growth regulator for grapes, c.v. KYOHO.

A safety risk for Mepiquat-chloride is not to be expected as far as it is used in accordance with the established safe use standard.

\section{Contact}

Registration Department, Agricultural Chemicals Division, BASF Japan Ltd. 3-3, Kioicho, Chiyoda-ku, Tokyo 102, Japan 問合せ

ビーエーエスエフジャパン株式会社農薬部登録課 干102 東京都千代田区紀尾井町 3-3 